\title{
Eosinophilic esophagitis -- clinical manifestations, diagnosis, and treatment
}

\author{
A. J. Lucendo Villarín \\ Department of Digestive Diseases. Complejo Hospitalario La Mancha Centro. General Hospital of Tomelloso. Alcázar \\ de San Juan-Tomelloso, Ciudad Real. Spain
}

\begin{abstract}
Eosinophilic esophagitis (EE) is a chronic inflammatory, immunoallergic disease of the esophagus that represents the most common eosinophilic gut disease. Understanding and diagnosis regarding this condition have greatly increased in recent years, particularly in Europe and North America, in parallel with other allergic disorders. It consists of dense esophageal infiltration with eosinophils in the absence of gastro-esophageal reflux (GER). It involves individuals at all ages, and is particularly common in males during childhood and up to the $5^{\text {th }}$ decade of life. It manifests with chronic, intermittent esophageal symptoms that predominantly include dysphagia, food impaction episodes, and GER-attributable complaints that do not respond to antisecretory therapy.

Endoscopically, EE is a polymorphous disease that presents with various changes in esophageal caliber, and subtle changes in mucosal appearance, which lead to biopsy collection as a key procedure for diagnosis. Management must be multidisciplinary, including gastroenterologists, pathologists, allergologists, and also nutrition specialists in pediatric cases.

Regarding therapy, dietary food restrictions are especially useful in the management of pediatric EE, but effectiveness is lower in the adult, maybe because of a greater involvement of air allergens. Drug use is standard, particularly involving topical steroids, which may revert manifestations and histological lesions, even though recurrence following discontinuation is common.
\end{abstract}

Key words: Eosinophilic esophagitis.

Lucendo Villarín AJ. Eosinophilic esophagitis -- clinical manifestations, diagnosis, and treatment Rev Esp Enferm Dig 2009; 101: 49-59.

Received: $23-07-08$

Accepted: 23-07-08.

Correspondence: Alfredo J. Lucendo Villarín. Sección de Aparato Digestivo. Hospital General de Tomelloso. Vereda de Socuéllamos, s/n. 13700 Tomelloso.Ciudad Real, Spain.e-mail: alucendo@vodafone.es

\section{INTRODUCTION}

The esophagus is a muscular organ that channels food from the pharynx to the stomach as a result of its anatomical structure, which is particularly adapted to motor function. Its squamous, stratified epithelial lining resembles the skin, lacks absorptive structures, and has scarce submucosal acinar glands that secrete lubricating mucus and bicarbonate. The contraction of its muscle layers, coordinated by Meissner's and Auerbach's plexuses, results in movements that advance the swallowed bolus by sequentially activating esophageal segments.

The gut wall is an extensive contact area with the outer environment whose primary role is serving as a physical barrier, and which also possesses mechanisms to identify the various substances and organisms contacted, to which it may respond for or against. The gut mucosa has a number of specialized structures and functions regarding this role, and permanently lodges cells of various immune stocks that warrant these functions. However, the esophageal wall's content in such cells is virtually negligible when compared to distal gut segments characterized by absorptive functions. While little attention has been traditionally paid to the role of the esophagus in immune responses, this organ also has a surveillance system, and inflammatory infiltration by eosinophils reflects an induction of its immune capacity.

We may define eosinophilic esophagitis (EE) as a chronic esophageal inflammatory disorder, immunoallergic in nature and of unknown origin that is characterized by dense infiltration by eosinophilic granulocytes that is restricted to the esophagus. This inflammation develops in the absence of pathological gastro-esophageal reflux (GER), and the condition presents with various esophageal and upper gastrointestinal tract complaints of highly variable frequency and duration (1). 


\section{EOSINOPHILIC ESOPHAGITIS: HISTORICAL NOTES}

Esophageal eosinophilic infiltration has a recent history. Its first mention in the literature was in 1977 when a 51-year-old male was described who had dysphagia and chest pain, a history of asthma and environmental allergy (2), and eosinophilic gastroenteritis (EG) with esophageal involvement. During the 1980s a number of papers defined the presence of eosinophils permeating the esophageal epithelium as a pathognomonic sign of gastro-esophageal reflux (3). This consideration represented a complication for the correct identification of many patients with esophageal eosinophilic infiltration who did not respond to conventional antisecretory therapy $(4,5)$. It was the work by Attwood et al. (6) that first defined $\mathrm{EE}$ as a distinct clinico-pathological syndrome that was independent from EG when they described 12 young patients with severe eosinophilic infiltration exclusively restricted to the esophagus, to a significantly greater extent than in GERD, and with distinct clinical characteristics. It was only one year later that Straumann et al. (7) published a paper on 10 patients with recurrent acute dysphagia; already in 1994, they noted that the prevalence of $\mathrm{EE}$ was underestimated, as this could be considered the most common form of eosinophilic enteropathy, and predicted greater recognition in the future. Shortly afterwards, Kelly et al. (8) described 10 children with esophageal eosinophilia and severe, long-standing GER symptoms refractory to anti-GER drugs and Nissen fundoplication, who after being fed with amino-acid mixtures lacking antigenic power for at least 6 months showed resolved $(n=8)$ or improved $(n=2)$ symptoms, epithelial eosinophilic infiltration, and mucosal reactive changes. Symptoms developed again on returning to a normal diet, which defined esophagitis from severe reflux with eosinophilia as a form of food allergy. The number of cases reported in the literature has continued to grow exponentially ever since.

EE has been considered an emergent disease $(9,10)$. However, its increased epidemiology also results from a better understanding of this disease by clinicians, who now consider it within the differential diagnosis of dysphagia, and of course by pathologists, a key part in the diagnostic process (11). During the last few years, figures available on the prevalence and incidence of this condition in developed countries have progressively increased: In 2004, Straumann et al. (12) estimated a prevalence of 1.43 cases $/ 10^{4}$ inhabitants/year among the Swiss adult population, similar to that seen in our healthcare area in Madrid (1.8 cases $/ 10^{4}$ inhabitants/year) (13) a year later. In the pediatric population the incidence in the USA for 2005 was estimated as 10 cases/10 $0^{4}$ inhabitants/year, with a cumulative prevalence of 43 patients $/ 10^{5}$. Reports during the last year estimate prevalence above 90 cases $/ 10^{5}$ inhabitants (14). However, we should here highlight the results from a recent epidemiological study performed in
Sweden, which estimates that up to 1 in every 100 inhabitants at Kalixandra had histological findings consistent with eosinophilic esophagitis in their biopsies regardless of symptoms (15).

$\mathrm{EE}$ cases reported in the literature are mainly from countries in Europe and North America, and to a lesser extent in Asia, South America, and Australia. This distribution affecting most developed areas parallels bronchial asthma and other atopic conditions, hence we may involve environmental and immune factors in common with other allergy forms in its etiopathogenesis (16).

More than $65 \%$ of EE cases develop during childhood (17), but the condition has also been described in patients of all ages (18). In contrast to other immunoallergic diseases, EE predominates in males regardless of age (more than $3 / 4$ of cases), and most commonly presents in adults during the $3^{\text {rd }}$ to $5^{\text {th }}$ decades of life (19).

\section{ETIOLOGY}

Multiple evidence supports the consideration of EE as an allergic disorder: a great majority of patients, both adults and children, have a personal and/or family history of atopy (asthma, rhinitis, conjunctivitis, drug and food allergies) $(20,21)$, frequent food $(22,23)$ and/or air allergen sensitization (24), blood eosinophilia, increased serum IgE levels, and positive results in multiple allergy skin tests and RAST. Elemental dieting, absence of selected foods, and anti-allergy therapies result in clinical and histological remission (25). In addition, parallel esophageal and bronchial eosinophilic inflammation has been reported for some EE patients on a seasonal basis $(26,27)$, as well as its development after food (28) or drug (29) ingestion. On all these grounds EE has been considered an immunoallergic disorder.

\section{CLINICAL MANIFESTATIONS}

$\mathrm{EE}$ is characterized by a number of nonspecific esophageal symptoms, both acute and chronic, that develop at highly variable ages (30). Also, these symptoms have a number of differences according to patient age. An extensive review of EE reported in 2002 (31) found that symptoms in adults included dysphagia, food impaction, vomiting, and chest pain, whereas children also have nausea, heartburn, epigastric pain, sialorrhea, food aversion, delayed growth, and respiratory complaints (cough, stridor, sinusitis, obstruction, pneumonia). $\mathrm{Pa}-$ tients commonly have a number of simultaneous EE-related symptoms at any age.

In children, the ability to effectively report symptoms determines various presentation forms for pediatric EE (32), hence the possibility of a time sequence for EE 
manifestations has been proposed (33); thus, smaller children (who cannot report dysphagia) would have a number of eating disorders including food aversion; later on, vomiting, regurgitation, and both chest and abdominal pain, mimicking gastro-esophageal reflux disease (GERD); from 11 years on, the condition would manifest with dysphagia and food impaction, which predominate in adults. It should be noted that patients eat dead slow, taking much longer that the rest of the family to complete a meal, and usually drink after each and every bite; parents should be asked for this during history-taking.

In adult patients intermittent dysphagia is the most common complaint, and occurs in more than $70 \%$ of cases in some series; however, food impaction is the symptom that most often leads to a diagnosis (56 to $88 \%$ of cases) (34). While less frequent, GERD symptoms are also commonplace (35). Overall, symptoms persist for a long time, even years, before a diagnosis is reached (36). Much less common complaints in adults include vomiting, chest or abdominal pain, and weight loss.

\section{ENDOSCOPIC FINDINGS}

EE has been, and still is, an underdiagnosed condition in many settings, since endoscopic findings are usually much subtler than those seen in esophageal growths or erosive disorders (37). A careful exam is therefore needed that should include biopsy samples from all suspect cases in order to ensure a proper diagnosis (38). From an endoscopic viewpoint EE has a great variety of potential findings (39-41) (Fig. 1). Literature reports include re-

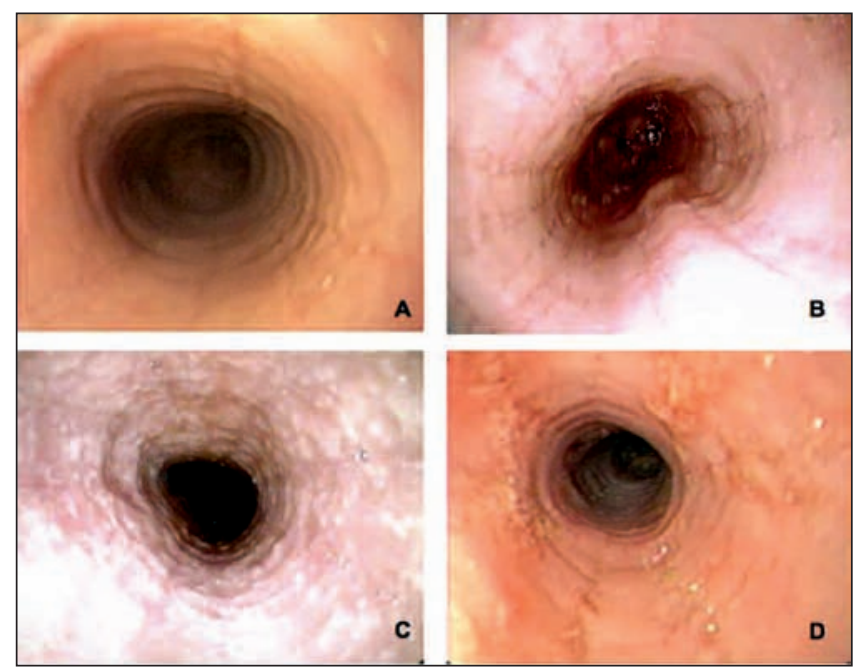

Fig. 1. Several endoscopic aspects of eosinophilic esophagitis. A: Normal-caliber esophagus with longitudinal linear furrows and smooth mucosa. B: Frail-looking, "crêpe paper" mucosa with marked mucosal corrugation. C: The esophageal mucosal surface may be covered in cotton-like exudates mimicking candiadiasis, but biopsy finds them to be multiple eosinophil-containing micro-abscesses. D: Reduced-caliber, trachealized esophagus with irregular, cobblestone appearance. duced esophageal caliber (42) as focal or segmentary stenoses, trachealized esophagus, irregular mucosa, reddish mucosa, whitish elevated papules that resemble candidiasis (43), longitudinal linear furrows (also called esophageal corrugation) (44), changes in esophageal mucosal pattern (45), mucosal frailty (46), esophageal tears (47), and food impaction $(11,30,36)$. A retrospective review of 117 patients with a histological diagnosis of $\mathrm{EE}$ showed that the esophagus had been reported normal in up to $24.79 \%$ of cases (39), which suggests that changes in this organ's appearance may be subtle enough to be overlooked by an endoscopist not used to this disease. This highly variable range of endoscopic findings may be classified according to two aspects (34): changes in esophageal caliber, which result from motor disturbances, and changes in mucosal surface, which are a consequence of epithelial inflammatory infiltration. The effect of esophageal smooth-muscle contraction manifests as concentric stenoses that block endoscope progression or as simultaneously contracting rings, which are also responsible for food impaction even in the presence of a normal caliber. The various changes seen on the organ's surface translate the different severities of histological epithelial lesions, and a direct correlation between endoscopic severity, histological severity, and eosinophilic inflammatory infiltration density and activation has been reported (34).

\section{HISTOPATHOLOGICAL FINDINGS}

The presence of eosinophils in the esophageal epithelium may be seen in many esophageal conditions (48), and of itself defines no particular disease, but should be assessed within the patient's clinical and pathological context. Eosinophilic infiltration in EE involves the entire esophagus, but often in a patchy manner. It is for this reason that a good diagnosis requires multiple biopsies at different levels. Various papers have reported that the density of eosinophilic infiltration is similar in the distal and proximal thirds of the esophagus $(49,50)$, and a good diagnostic strategy involves collecting samples from both these thirds (1). Number of biopsies is relevant for diagnostic sensitivity, as the latter increases with sample number and reaches $100 \%$ with 5 biopsy specimens (51).

The most characteristic finding is a high number of eosinophils infiltrating the esophageal epithelium. The usual assessment approach is their count in fields more densely inflamed using an x400 lens (number per highpower field (HPF), $\mathrm{x} 400$ ). However, this measurement is non-standard as the area included in a HPF varies from one microscope manufacturer to the next. The threshold number of eosinophils in diagnosing $\mathrm{EE}$ also varies among authors $(6,11,52-55)$, but it is currently accepted that 15 eosinophils/HPF would suffice in the presence of a consistent clinical context when other histopathological 
findings are noted (1). Eosinophils may be diffusely distributed throughout the epithelial thickness, but tend to be more numerous in apical strata near the esophageal lumen (50) (Fig. 2). In cases with higher numbers they usually coalesce and make up micro-abscesses (56), which may eventually destroy the superficial epithelium (34). Extracellular eosinophilic granules and major basic protein (MBP) deposition, both extracellularly (57) and within the cytoplasm $(30,50,58)$, may be seen. Micro-abscesses, extracellular deposition of eosinophilic proteins, and positive immunostaining for MBP are findings exclusive of EE that are not seen in GERD (59).

Good biopsies allow the study of other histopathological findings characteristic of $\mathrm{EE}$, including basal layer hyperplasia with acanthosis or presence of proliferative

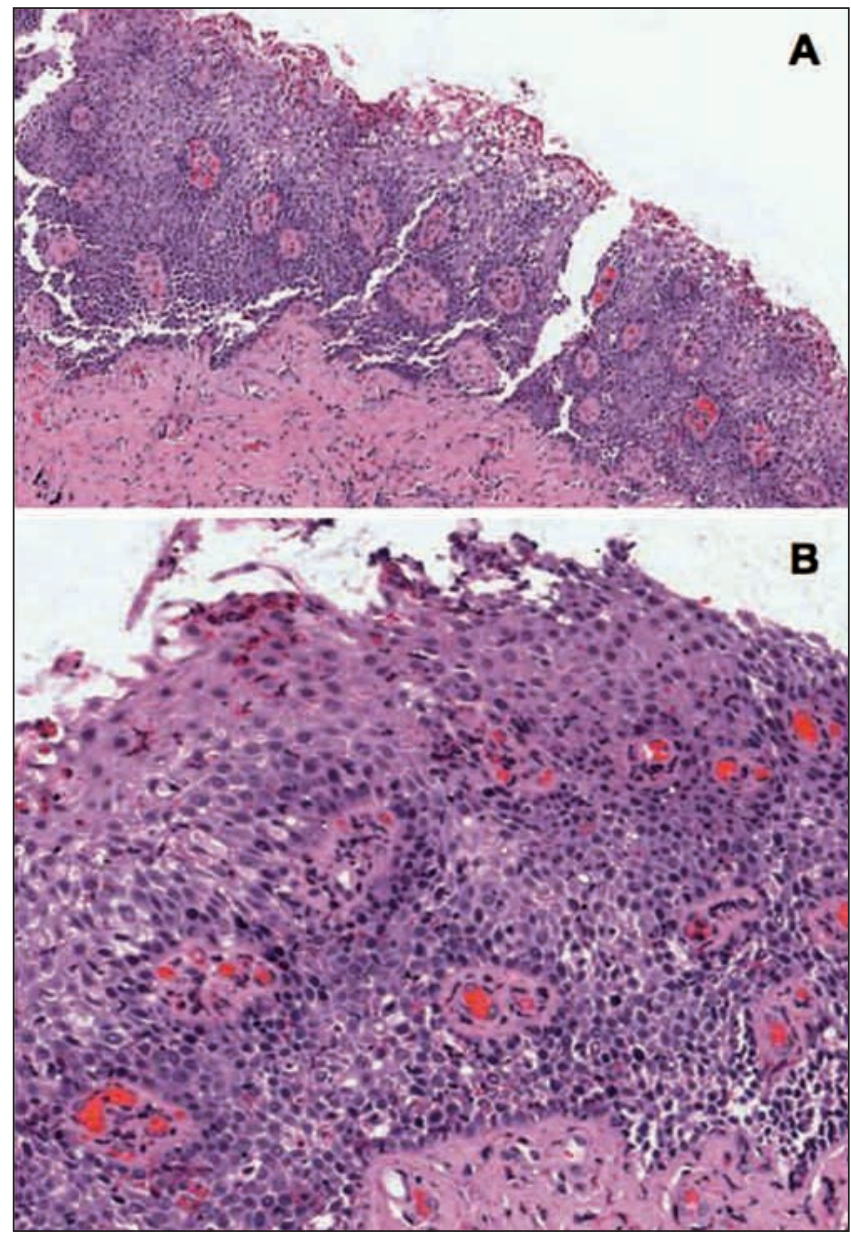

Fig. 2. Histopathological findings characteristic of eosinophilic esophagitis: A: Highly cellular esophageal epithelium with basal stratum proliferation and prominent papillas entering the epithelium from the lamina propria with congestive vessels. Many eosinophils may be found within the full-thickness mucosa, more abundantly in superficial strata by the organ's lumen. In B, described changes may be seen in greater detail, in addition to intercellular spaces, eosinophilic granules, and converging eosinophils that make up micro-abscesses in the esophageal apical surface (hematoxylin and eosin, $x 200$ and $x 300$, respectively). stratum cells in higher epithelial levels, elongated papillas in the lamina propria, and intercellular edema, reflected by enlarged intercellular spaces. These findings translate a nonspecific, proliferative epithelial response (34), as may also be seen in GERD (60-62).

Subepithelial collagen deposition has been reported within the esophageal lamina propria of pediatric patients with $\mathrm{EE}$ to a significantly greater extent versus normal conditions and GERD $(57,63)$, which occurs via a mechanism dependent on TGF $\beta$ and its signaling molecule pSMAC2/3, which implies angiogenesis and cellular migration (57). Murine EE models have established that the organ's fibrous remodeling results from specific tissue eosinophilia as induced by interleukin (IL) 5 (64). No data are available regarding the clinical implications of subepithelial fibrosis in EE or its potential reversibility (65), but the rest of histopathological findings usually regress to normal after therapy (Fig. 3).

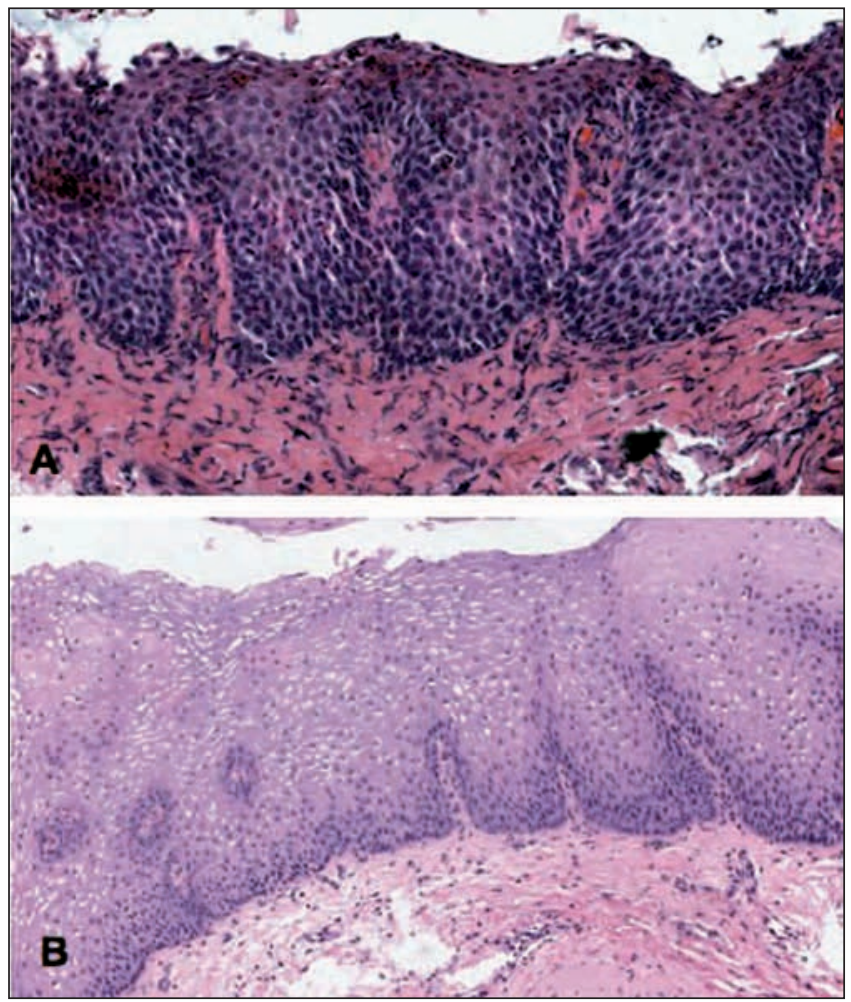

Fig. 3. Images corresponding to this same patient before and after therapy with topical steroids to illustrate changes in the esophageal epithelium: A shows marked epithelial proliferation with basal-cell hyperplasia (more basophilic, polygonal in shape) reaching up to superficial strata, in addition to elongated connective papillas, which appear thicker and hypervascularized. Numerous eosinophils aggregate on the epithelium's surface. After 6 months under treatment with fluticasone propionate (B) the esophageal epithelium exhibits fewer cells and recovered stratification, with basal cells occupying not more than $15 \%$ of esophageal thickness, and no eosinophilic infiltration (hematoxylin and eosin, x200). 


\section{MOTOR DISTURBANCES IN EE}

Eosinophilic infiltration in the human gut is associated with various gastrointestinal motility disorders (66-68). Pediatric patients with EE have been studied with endoscopic ultrasonography, which shows a thickening of the esophageal mucosa and submucosa (69), as well as the muscularis propria (70). Murine models exhibit a dense infiltration of the esophageal muscle with eosinophils (71), which has also been seen in humans (72). A number of motor disorders associated with EE have been reported in the literature, which may be identified with stationary manometry. These include vigorous achalasia (72), diffuse esophageal spasm $(73,74)$, nutcracker esophagus $(6,75)$, high-amplitude peristaltic waves $(76,77)$, tertiary waves $(74,78)$, tone and lower esophageal sphincter functional changes $(72,73,79)$, and nonspecific disorders characterized by low-amplitude, non-transmitted waves with frequent simultaneous sequences (79). Normal manometry recordings have also been described $(73,75,77,80,81)$. Regarding age, disorders characterized by potent, wide waves involving the distal esophagus predominate during childhood; these waves are often concurrent and also develop during sleep and interprandial periods, when the esophagus should remain at rest. On the other hand, the range of motor disorders is wider in adult patients, and includes recordings similar to those of children, but also disorders characterized by low-amplitude, non-transmitted waves in the distal esophagus. Motor disorders predominantly involve the distal two-thirds of the esophagus, which are made up of smooth muscle. Eosinophils themselves have been implicated in the origin of motor disorders; via MBP they influence smooth muscle fibers, since the former is a powerful agonist that can bind the acetylcholine (Ach) M2 receptors governing smooth-muscle function $(82,83)$.

In addition, mast cells in tissue eosinophilic infiltrates (84) also can induce smooth muscle contraction via histamine activity, which induces Ach release and may also alter neuron membrane potential in esophageal plexuses (85), and through their contents in leukotriene $\mathrm{C} 4$, another direct stimulant of smooth-muscle contraction.

An association between type of motor disorder and symptom duration has been established in EE (86) in such a way that adults with shorter illness have hyperkinetic disorders similar to those seen in children, whereas those with longer-standing symptoms have hypokinetic manometry recordings. A time progression for this motor disorder has been thus suggested where, following an initial hyperkinetic stage, the esophagus becomes 'exhausted' in a way not unlike achalasia $(77,86)$.

Anyway, evidence suggests that the motor disorder is reversible with treatment once the organ's eosinophilic infiltration is resolved $(65,77)$, which reinforces its functional origin.

\section{DIAGNOSTIC STRATEGY}

EE must be suspected for any patient, particularly if young and with a history of allergy, with esophageal symptoms, specifically dysphagia, history of food impaction, or GER-like complaints unresponsive to acid secretion inhibitors. These patients must undergo endoscopy with biopsy collection, at least 5 samples preferentially from the proximal and distal thirds. Samples from the duodenum and gastric antrum should also be collected during endoscopy, while trying to exclude eosinophilic gastroenteritis.

Following the histopathological analysis GER should be excluded as a cause of esophageal eosinophilia (1), albeit the latter condition rarely presents with such dense eosinophilic infiltrates. To this end 24-hour $\mathrm{pH}$-metry recordings should be obtained; should these be pathological or unavailable, esophageal biopsies should be repeated following therapy with maximal-dose proton-pump inhibitors for at least 8 weeks.

At diagnosis the patient should be studied at an Allergy Unit -allergic sensitization, always frequent in these individuals, must be adequately defined, since food and environmental allergens have been implicated in the pathogenesis of EE.

Table I shows the current diagnostic criteria for EE (87).

Table I. Diagnostic criteria for eosinophilic esophagitis (modified from Gonsalves N) (87)

\begin{tabular}{lll}
\hline & Adults & Children \\
\hline -Symptoms & Dysphagia & Abdominal pain \\
& Food impaction & Heartburn \\
& Heartburn & Regurgitation \\
& Regurgitation & Nausea/Nomiting \\
& Chest pain & Dysphagia \\
& Odynophagia & Failure to thrive \\
\hline
\end{tabular}

-Histology

- Esophageal biopsy with $\geq 15$ eosinophils / HPF

- Normal gastric and duodenal biopsies

- 24-hour pH-metry with no pathological GER, or biopsies obtained after 6-8 weeks under dual-dose proton-pump inhibitors

HPF: high-power field (400x)

\section{EE AND GERD}

EE and GERD share a number of aspects and may look similar on endoscopy, histology, and manometry. In addition, some patients with EE may improve their symptoms with antisecretory medication. Acid reflux does not seem to contribute to EE pathogenesis (88), but the complex pathological links between EE and GERD should be explored $(89,90)$ in order to define whether these two dis- 
orders are independent from each other (91), whether GERD-induced damage may cause EE (92), or whether EE may be determinant for GERD, mainly through motor dysfunction at the distal esophagus or lower esophageal sphincter.

\section{TREATMENT OF EE}

\section{Dietary management}

In 1995 Kelly et al. (8) attained clinical and histological remission in 10 children with GER-attributed eosinophilic esophagitis using elemental diet, but symptoms recurred following the reintroduction of a free diet. In addition to defining esophagitis from severe reflux as dense eosinophilic infiltration, this work established the "gold standard" in the treatment of EE. However, elemental diet has many shortcomings including poor palatability that often requires tube feeding, a high cost, need to closely monitor nutritional deficiency, and unviability for chronic use and adult patients. Hence other alternatives have been attempted including the exclusion of allergic sensitization-related foods, or of potentially allergenic foods, from the diet. Identifying causative food allergens during history taking or via their relation to symptom development is challenging since in most cases inflammation develops within days after exposure due to the delayed hypersensitivity reaction that mediates this condition's pathophysiology. Furthermore, inflammation persists several days after food ingestion, and may result from more than one type of food.

The exclusion of sensitizing foods as seen in allergy tests was successful in a study by Spergel et al. (25), who identified specific foods in 77 of 146 pediatric patients. The disease was adequately managed for $77 \%$ of cases, but $10 \%$ showed no improvement. A mean of up to 5 foods responsible for EE were identified per patient, and 39 cases worsened after normal diet reintroduction. These results have not been reproduced by other teams, probably due to the fact that allergology methods have variable sensitivity and specificity, mainly because of patch test standardization. It is important, particularly for children, that potential nutrient deficiencies be avoided, since food restriction may become extensive; the participation of a nutrition specialist is recommended.

The third dietary strategy is the suppression of foods considered allergenic. Its initial application in a series of 35 children with EE included the exclusion of 6 products from the diet (milk, soy, eggs, wheat, peanuts, walnuts, fish) regardless of sensitization (93). Following this 34 patients improved or got rid of their symptoms while eosinophil numbers in epithelial infiltrates significantly decreased (from 80.2 to $13.6 / \mathrm{HPF}$ ). A study in adults using this same strategy yielded partial results (94), with symptom improvement in only $30 \%$ of cases, and incom- plete histological regression. Reasons accounting for these differences include that adult EE seems related to airborne allergens rather than inhalants. To conclude, while an empirical exclusion of foods is easy to implement, it might not eliminate a food necessary for remission, or may be too strict and include unnecessary exclusions.

\section{Drug therapy}

Drug therapy for EE is problematic in several ways -unavailability of drugs specifically approved for this condition, a chronic course that discourages long-term drug administration, or absence of definite long-term prognostic data on EE and its potential complications to avert the risk of prolonged systemic treatment. Furthermore, none of these therapies has proven adequate to modify the course of disease in the long run, or to prevent complications from arising (e.g., fibrous esophageal stenoses) (13). However, symptom frequency and severity, the risks of repeated endoscopic procedures, and quality of life involvement requires a number of therapies, as follows.

-Proton-pump inhibitors (1): acid suppression in EE is necessary to rule out GERD as a cause of esophageal eosinophilia when $\mathrm{pH}$-metry is unavailable, or pathological, and also in patients with concomitant EE and GER (91). Thus, while acid secretion inhibitors should not be considered specific for EE, they may contribute to relieve associated symptoms in some individuals.

-Systemic corticosteroids (prednisone): since 1996 several experiences show their effectiveness after oral administration $(78,95,96)$ at doses of 0.5 to $1.5 \mathrm{mg} / \mathrm{kg} / \mathrm{day}$. However, the disease recurs within months after discontinuation, which, together with adverse effects from chronic use in pediatric patients, discourages their use in favor of safer alternatives.

-Topical corticoesteroids: fluticasone propionate is most commonly used given its characteristics, which render it particularly suitable for EE -- low systemic bioavailability through the inhaled route (negligible through the gastrointestinal route, $<1 \%$ ), liver first-pass effect approaching 99\%, non-absorbable by the esophageal mucosa, instability in an acid medium. Since first described in EE (97), both in children $(53,75,98$ $101)$ and adults $(11,28,34,50,77,102,103)$ it has shown a therapeutical effectiveness similar to systemic steroids (104), while adverse effects are kept to a minimum. This treatments's main shortcoming is its difficult administration -- it is usually available in devices for inhalation, and for EE must be swallowed after applying it on the tongue. Hence successful treatment greatly depends on adequately instructing the patient on how the drug should be used. A liquid fluticasone preparation for nasal use is available in our country that may be easier to use in EE. The pa- 
tient must be instructed not to eat or drink for at least 30 minutes following administration, otherwise the steroid would be washed into the stomach; a mouthwash should also be recommended after use to prevent oral candidiasis. Difficulties for adequate administration to pediatric patients may be overcome by using viscous budesonide $(57,101)$, which adequately covers the entire esophagus, and is safe and effective. Fluticasone doses range from $176 \mu \mathrm{g} /$ day in children up to 4 years of age to 1,000 $\mu \mathrm{g} /$ day in adults (in two administrations) for 6 to 12 weeks. As for budesonide, commonly used doses are 1-2 $\mathrm{mg}$ /day in 8-12 $\mathrm{mL}$ once a day.

-Mast-cell stabilizing substances (disodium cromoglycate) had bee put to good use in EG for their resistance to gastric acidity (105). In EE, Liacouras et al. (52) used up to $100 \mathrm{mg}$ daily (in four doses) in a series of 14 children with EE, and observed no clinical or histological improvement at 1 month after treatment onset, hence the drug cannot be recommended for this disease.

-Anti-leukotrienes: Montelukast has been tried in a series of 8 patients with EE (106) at very high doses (> $100 \mathrm{mg} /$ day). After several weeks 7 reported symptom remission, and the rest symptom improvement. However, in no case did esophageal histology return to normal. Another study that measured gene expression levels for cysteinyl-leukotrienes in the esophageal epithelium found them similar in children with EE and normal controls (107). While Montelukast does not seem to achieve remission in this disease, we still do not know its efficacy in maintaining corticoid-induced remission.

-Azathioprine/6-mercaptopurine: a study in three adult patients with steroid-dependent EE (108) who received immunomodulation with purine analogs showed symptom and eosinophilic infiltration remission during therapy (from 3 to 8 years) with no need for steroids. Upon discontinuation the disease recurred in two patients.

-MepolizumAb is a humanized monoclonal antibody against IL-5, a TH2 cytokine that plays a key role in the proliferation, differentiation, survival, and activation of eosinophils in chronic allergic airway conditions (109) and in EE $(110,111)$, both in humans (112) and animal models (113). Its use has been successful in EG (114) and hypereosinophilic syndrome (115), and more recently in EE (116). A double-blind, randomized, placebo-controlled clinical trial is now ongoing in adult patients with EE, where mepolizumAb has demonstrated good tolerability and a highly significant reduction in eosinophil numbers both in the blood and esophagus, with no changes induced on other inflammatory cells or on the expression of other proinflammatory cytokines in the blood (117). OmalizumAb (anti$\mathrm{IgE})(118)$ has not proven effective in EE.

\section{Endoscopic management}

Esophageal food impaction is the complaint most commonly leading to a diagnosis of $\mathrm{EE}$ in adult patients
(34), and often requires urgent management with endoscopy. Patient age, previous repeat impactions, and potential allergic history should be considered for EE suspicion. The exam should focus on the presence of stenoses or esophageal rings, and of the above-mentioned mucosal changes; also, if EE is suspected, biopsy samples should be collected from the organ's mucosa, even if its appearance is considered normal.

Endoscopic dilations are a common therapy for fibrous or rigid stenoses secondary to long-term inflammation healing involving the gut mucosa. Esophageal stenosis dilation in EE has been used by several authors in the management of this condition $(40,46,100,119)$, and provided immediate symptom relief $(120,121)$. However, various complications have also been reported with this technique, more frequently in EE versus other conditions, including perforations (122-124), hematomas (125), and unusual tears, the latter particularly common during rigid endoscopy (47). Therefore, endoscopic dilation is a risky therapy in these individuals (126) that should be avoided first-line until eosinophilic infiltration can be effectively ruled out, and reserved for symptomatic patients where medical treatment failed (127).

\section{EE management controversies}

Multiple controversies exist on the management of $\mathrm{EE}$, both in children and adults, that currently have no definite scientific answer. EE, as other allergic conditions, is a chronic condition where eosinophilic infiltration and symptoms usually recur after treatment discontinuation. Adult (128) and pediatric (52) series followed up for 10 or more years show a chronic course in most patients, and progressive disease in severe cases; spontaneous resolution is rare. Whether disease persists in all children until adulthood is unknown -- many adults report symptoms since childhood (65), whereas others have a limited duration. EE has been considered a risk factor for esophageal perforation from vomiting or endoscopic procedures, and may predispose to fungal or viral infection (123). While it does not seem to limit life expectancy, it does substantially affect quality of life, even though many patients eventually learn to live with their symptoms. The clinical relevance of long-term epithelial fibrous remodeling is unclear, but patients with longerstanding symptoms may have reduced response to therapy (128).

All this leads to consider maintenance therapy for EE, similar to other allergic conditions such as bronchial asthma, but definitive data on their risks and cost is as of yet unavailable.

Now we know that EE symptoms may fluctuate spontaneously, or even stay in stand-by even with persistent eosinophilic infiltrates in histological studies. A consensus reached by an expert committee on EE (1) has recom- 
mended treatment for histology even in the absence of symptoms, due to the potential risks posed by esophageal fibrosis and remodeling, and stenosis formation.

The established scarce predictability of symptoms on inflammation has led to consider endoscopy with biopsy collection in the management and follow-up of patients, as well as in the evaluation of food withdrawal or introduction effects. Therefore, endoscopic exams under sedation should be carried out in all these patients.

While most children and adults with EE have atopy and experience a number of other allergic manifestations (asthma, rhinoconjunctivitis, eczema, etc.), there is also a small group of subjects with EE symptoms and histopathology in the absence of other atopy complaints. In these allergy tests yield no positive results, and no response to elemental diet is seen among children (32). All these patients successfully respond to topical steroids, but disease recurs upon their discontinuation. Whether all these patients have the same disease, or whether EE pathophysiology is one throughout the complete clinical spectrum is unclear (16), but several cytokine gene expression profiles have now been demonstrated in patients with EE (112). Anyway, allergy should be adequately studied in all patients, since food or environmental allergies triggering the condition should be identified; adequate exposure control would be a cheap, effective, safest therapy, regardless of drug therapy needs.

\section{CONCLUSIONS}

EE is a chronic (both clinically and histologically) disease with an incidence much higher than previously thought, and that may substantially compromise patient quality of life. Adequate management requires cooperation by gastroenterologists, allergists, and pathologists, as it represents an emerging diagnostic and therapeutic challenge in view of its growing epidemiology. It should be suspected in any patient with refractory GER symptoms, or with dysphagia and food impaction, most particularly in young males with a history of allergy. Diagnostic suspicion should prompt biopsy collection even from a normal-looking esophagus. Diet therapy and allergen exposure control are most desirable; otherwise, topical steroids are currently the first-choice therapy for this disease.

\section{ACKNOWLEDGMENTS}

We are grateful to Dr. José Luis Yagüe-Compadre at Pathology Department, Complejo Hospitalario Mancha Centro, for the histological images illustrating this paper.

\section{REFERENCES}

1. Furuta GT, Liacouras CA, Collins MH, Gupta SK, Justinich C, Putman PE, et al. Eosinophilic esophagitis in children and adults: a systematic review and consensus recommendations for diagnosis and treatment. Gastroenterology 2007; 133 (4): 1342-63.

2. Dobbins JW. Eosinophilic gastroenteritis with esophageal involment. Gastroenterology 1977; 72 (6): 1312.

3. Winter HS, Madara JL, Stafford RJ, Grand RJ, Quinlan JE, Goldman H. Intraepitelial eosinophils: a new diagnostic criterion for reflux esophagitis. Gastroenterology 1982; 83 (4): 818-23.

4. Brown LF, Goldman H, Antonioli DA. Intraepitelial eosinophils in endoscopic biopsies of adults with reflux esophagitis. Am J Surg Pathol 1984; 8 (12): 899-905.

5. Picus D, Frank P. Eosinophilic esophagitis. Am J Roentgenol 1981; 136 (5): 1001-3.

6. Attwood SE, Smyrk TC, Demeester TR, Jones JB. Esophageal eosinophilia with dysphagia. A distinct clinicopathologic syndrome. Dig Dis Sci 1993; 38 (1): 109-16.

7. Straumann A, Spichtin HP, Bernoulli R, Loosli J, Vogtlin J. Idiopathic eosinophilic esophagitis: a frequently overlooked disease with typical clinical aspects and discrete endoscopic findings. Schweiz Med Wochenschr 1994; 124 (33): 1419-29.

8. Kelly KJ, Lazenby AJ, Rowe PC, Yardley JH, Perman JA, Sampson HA. Eosinophilic esophagitis attributed to gastroesophageal reflux: improvement with an amino acid-based formula. Gastroenterology 1995; 109 (5): 1503-12.

9. Lucendo AJ, Carrión G, Navarro M, Pascual JM, González P, Castillo P, et al. Eosinopilic esophagitis in adults: an emerging disease. Dig Dis Sci 2004; 49 (11-12): 1884-8.

10. Collardeau-Frachon S, Hervieu V, Scoazec JY. Eosinophilic esophagitis: an "emerging disease". Ann Pathol 2007; 27 (6): 417-25.

11. Lucendo Villarín AJ, Carrión Alonso G, Navarro Sánchez M, Martín Chávarri S, Gómez Senent S, Castillo Grau P, et al. Eosinophilic eosinophilic in adults, an emerging cause of dysphagia. Description of 9 cases. Rev Esp Enferm Dig 2005: 97 (4): 229-39.

12. Straumann A, Simon HU. Eosinophilc esopahagitis: Escalating epidemiology? J Allergy Clin Inmunol 2005; 115 (2): 418-9.

13. Lucendo AJ. Esofagitis eosinofilica. Med Clin (Barc) 2007; 128 (15):590-7.

14. Buckmeier BK, Rothenberg ME, Collins MH. The incidence and prevalence of eosinophilic esophagitis. J Allergy Clin Immunol 2008; 121 (2): (Supl. 1): S-71.

15. Ronkainen J, Talley NJ, Aro P, Storskrubb T, Johansson SE, Lind T, et al. Prevalence of esophageal eosinophils and eosinophilic esophagitis in adults: the population-based Kalixandra study. Gut 2007; 56 (5): 615-20.

16. Blanchard C, Rothenberg ME. Basic pathogenesis of eosinophilic esophagitis. Gastrointestinal Endosc Clin North Am 2008; 18 (1): $133-43$.

17. Liacouras CA, Bonis P, Putman PE, Straumann A, Ruchelli E, Gupta SK, et al. Summary of the First International Gastrointestestinal Eosinophil Research Symposium. J Pediatr Gastroenterol Nutr 2007; 45: 370-91.

18. Liacouras C. Eosinophilic esophagitis in children and adults. J Pediatr Gastroenterol Nutr 2003; 37: S23-8.

19. Lucendo Villarín AJ, De Rezende L. Esofagitis eosinofílica: revisión de los conceptos fisiopatológicos y clínicos actuales. Gastroenterol Hepatol 2007; 30 (4): 234-41.

20. Meyer GW. Eosinophilic esophagits in a father and a daugther. Gastrointest Endosc 2005; 61 (7): 932.

21. Nielsen RG, Husby S. Eosinophilic oesophagitis: epidemiology, clinical aspects, and association to allergy. J Pediatr Gastroenterol Nutr 2007; 45 (3): 281-9.

22. Spergel JM. Eosinophilic esophagitis in adults and children: evidence for a food allergy component in many patients. Curr Opin Allergy Clin Immunol 2007; 7 (3): 274-8.

23. Armisén M, Vidal C, López-Rosés L, Rodríguez V, Bartolomé B. Eosinophilic esophagitis due to allergy to sheep and goat milk proteins. Rev Esp Enferm Dig 2008; 100 (1): 53-6.

24. Simon D, Marti H, Heer P, Simon HU, Braathen LR, Straumann A. Eosinophilic esophagitis is frequently associated with IgE-mediated al- 
lergic airway diseases. J Allergy Clin Inmunol 2005; 115 (5): 1090-2.

25. Spergel JM, Andrews T, Brown-Whitehorn TF, Beausoleil JL, Liacouras CA. Treatment of eosinophilic esophagitis with specific elimination diet directed by a combination of skin prick and patch test. Ann Allergy Asthma Immunol 2005; 95 (4): 336-43.

26. Fogg MI, Ruchelli E, Spergel JM. Pollen and eosinophilic esophagitis. J Allergy Clin Inmunol 2003; 112 (4): 796-7.

27. Spergel JM. Eosinophilic esophagitis and pollen. Clin Exp Allergy 2005; 35 (11): 1421-2.

28. Martín-Muñoz MF, Lucendo AJ, Navarro M, Letrán A, Martín-Chávarri S, Burgos E, et al. Food allergy and eosinophilic esophagitis: two cases studies. Digestion 2006; 74 (1): 49-54.

29. Balatsinou C, Milano A, Caldarella MP, Laterza F, Pierdomenico $\mathrm{SD}$, Cuccurullo F, et al. Eosinophilic esophagitis is a component of the anticonvulsant hypersensitivity syndrome: description of two cases. Dig Liver Dis 2008; 40 (2): 145-8.

30. Desai TK, Stecevic V, Chang C-H, Goldstein NS, Badizadegan K, Furuta GT. Association of eosinophilic inflamation with esophageal food impactation in adults. Gastrointest Endosc 2005; 61 (7): 795-801.

31. Fox VL, Nurko S, Furuta GT. Eosinophilic esophagitis: It's not just kid's stuff. Gastrointest Endosc 2002; 56 (2): 260-70.

32. Putnam PE. Eosinophilic esophagitis in children: clinical manifestations. Gastrointestinal Endosc Clin North Am 2008; 18 (1): 11-23.

33. Noel RJ, Putman PE, Rothenberg ME. Eosinophilic esophagitis. The New England J Med 2004; 26: 940-1.

34. Lucendo AJ, Pascual-Turrión JM, Navarro M, Comas C, Castillo P, Letrán A, et al. Endoscopic, bioptic and manometric findings in eosinophilic esophagitis before and after steroid therapy: a case series. Endoscopy 2007; 39 (9): 765-71.

35. Katzka DA. Demographilc data and symptoms of eosinophilic esophagitis in adults. Gastrointestinal Endosc Clin North Am 2008; 18 (1): $25-32$.

36. Sgouros SN, Bergele C, Mantides A. Eosinophilic esophagitis in adults: a systematic review. Eur J Gastroenterol Hepatol 2006; 18 (2): 211-7.

37. Fox VL. Eosionophilic esophagitis: endoscopic findings. Gastrointestinal Endosc Clin North Am 2008; 18 (1): 45-57.

38. Straumann A, Beglinger C. Eosinophilic esophagitis: the endoscopist's enigma. Gastrointest Endosc 2006; 63 (1): 13-5.

39. Müller S, Pühl S, Vieth M, Stolte M. Analysis of symptoms and endoscopic findings in 117 patients with histological diagnoses of esinophilic esophagitis. Endoscopy 2007; 39 (4): 339-44.

40. Croese J, Fairley SK, Masson JW, Chong AKH, Whitaker DA, Kanowski PA, et al. Clinical and endoscopic features of eosinophilic esophagitis in adults. Gastrointest Endosc 2003; 58 (4): 516-22.

41. Sgouros SN, Bergele C, Mantides A. Eosinophilic esophagitis in adults: What is the clinical significance? Endoscopy 2006; 38 (5): 515-20.

42. Vasilopoulos S, Murphy P, Auerbach A, Masssey BT, Shaker R, Stewart E, et al. The small-caliber esophagus: an unappreciated cause of dysphagia for solids in patients with eosinophilic esophagitis. Gastrointest Endosc 2002; 55 (1): 99-106.

43. Lim JR, Gupta SK, Croffie JM, Pfefferkorn MD, Molleston JP, Corkins MR, et al. White specks in the esophageal mucosa: an endoscopic manifestation of non-reflux eosinophilic esophagitis in children. Gastrointest Endosc 2004; 59 (7): 835-8.

44. Langdon DE. "Congenital" esophageal stenosis, corrugated ringed esophagus, and eosinophilic esophagitis. Am J Gastroenterol 2000; 95 (8): 2123-4.

45. Straumann A, Spichtin HP, Bucher KA, Heer P, Simon HU. Eosinophilic esophagitis: red on microscopy, white on endoscopy. Digestion 2004; 70 (2): 109-16.

46. Straumann A, Rossi L, Simon HU, Heer P. Fragility of the esophageal mucosa: a pathognpmonic endoscopic sign of primary eosinophilic esophagitis? Gastrointest Endosc 2003; 57 (3): 407-12.

47. Straumann A, Bussmann C, Zuber M, Vannini S, Simon HU, Schoepfer A. Eosinophilic Esophagitis: analysis of Food Impaction and Perforation in 251 Adolescent and Adult Patients. Clin Gastroenterol Hepatol 2008; 6 (5); 598-600.

48. Rothenberg ME, Mishra A, Brandt EB, Hogan SP. Gastroeintestinal eosinophils. Inmunol Rev 2001; 179: 139-55.

49. Mueller S, Aigner T, Neureiter D, Stolte M. Eosinophil infiltration and degranulation in esophageal mucosa from adult patients with eosinophilic esophagitis (EE). A retrospective comparative pathologic biopsy study. J Clin Pathol 2006; 59 (11): 1175-80.

50. Lucendo AJ, Navarro M, Comas C, Pascual JM, Burgos E, Santamaría L, et al. Immunophenotypic characterisation and quantification of the epithelial inflammatory infiltrate in eosinophilic esophagitis through stereology: an analysis of the disease's cellular mechanisms and the esophagus's immunological capacity. Am J Surg Pathol 2007; 31 (4): 598-606.

51. Gonsalves N, Policarpio-Nicolás M, Zhang Q, Rao MS, Hirano I. Histopathologic variability and endoscopic correlates in adults with eosinophilic esophagitis. Gastrointest Endosc 2006; 64 (3): 313-9.

52. Liacouras CA, Spergel JM, Ruchelli E, Verma R, Mascarenhas M, Semeao E, et al. Eosinophilic esophagitis: a 10 year experience in 381 children. Clin Gastroenterol Hepatol 2005; 3 (12): 1198-206.

53. Noel RJ, Putman PE, Collins MH, Assa'ad AH, Guajardo JR, Jameson SC, et al. Clinical and inmunopathologic effects of swallowed fluticasone for eosinophilic esophagitis. Clin Gastroenterol Hepatol 2004; 2 (7): 568-75.

54. Blanchard C, Wang N, Stringer KF, Mishra A, Fulkerson PC, Abonia JP, et al. Eotaxin-3 and a uniquely conserved gene-expression profile in eosinophilic esophagitis. J Clin Invest 2006; 116 (2): 536-47.

55. Lucendo AJ, De Rezende L, Martín-Plaza J, Larrauri J. Esophageal granular cell tumor and eosinophilic esophagitis: two interesting entities identified in the same patient. Case Rep Gastroenterol 2008; 2: 33-9.

56. Cheung KM, Oliver MR, Vameron DJS, Catto-Smith AG, Chow CW. Esophageal eosinophilia in children with dysphagia. J Pediatr Gastroenterol Nutr 2003; 37 (4): 498-503.

57. Aceves SS, Newbury RO, Dohil R, Bastian JF, Broide DH. Esophageal remodeling in paediatric eosinophilic esophagitis. J Allergy Clin Immunol 2007: 119 (1); 206-12.

58. Parfitt JR, Gregor JC, Suskin NG, Jawa HA, Driman DK. Eosinophilc esophagitis in adults: distinguishing features from gastroesophageal reflux disease: a study of 41 patients. Mod Pathol 2006; 19 (1): 90-6.

59. Collins MH. Histopathologic features of eosinophilic esophagitis. Gastrointestinal Endosc Clin North Am 2008; 18 (1): 59-71.

60. Orlando RC. Pathophysiology of gastroesophageal reflux disease. J Clin Gastroenterol 2008;42 (5):584-8.

61. Caviglia R, Ribolsi M, Gentile M, Rabitti C, Emerenziani S, Guarino $\mathrm{MP}$, et al. Dilated intercellular spaces and acid reflux at the distal and proximal oesophagus in patients with non-erosive gastro-oesophageal reflux disease. Aliment Pharmacol Ther 2007; 25 (1): 62936.

62. Farre R, van Malenstein H, de Vos R, Geboes K, Depoortere I, Vanden Berghe P, et al. Short exposure of oesophageal mucosa to bile acids, both in acidic and weakly acidic conditions, can impair mucosal integrity and provoke dilated intercellular spaces. Gut 2008 (in press).

63. Chehade M, Sampson HA, Morotti RA, Magid MS. Esophageal subepithelial fibrosis in children with eosinophilic esophagitis. J Pediatr Gastroenterol Nutr 2007; 45: 319-28.

64. Mishra A, Wang M, Pemmaraju VR, Collins MH, Fulkerson PC, Albonia JP, et al. Esophageal remodeling develops as a consequence of tissue especific IL-5-induced eosinophilia. Gastroenterology 2008; 134 (1): 204-14

65. Lucendo AJ. Motor disturbances participate in the pathogenesis of eosinophilic oesophagistis, beyond the fibrous remodelling of the oesophagus. Aliment Pharmacol Ther 2006; 24 (8): 1264-7.

66. Attwood SE. Eosinophilis and gut dysmotility. Eur J Gastroenterol Hepatol 2005; 17 (9): 891-2.

67. Martin ST, Collins CG, Fitzgibbon J, Lee G, Quigley EM, O'Sullivan GO. Gastric motor dysfunction: is eosinophilic mural gastritis a causative factor? Eur J Gastroenterol Hepatol 2005; 17 (9): 983-6.

68. Scaillon M, Cadranel S. Food allergy and constipation in childhood: how functional is it? Eur J Gastroenterol Hepatol 2006; 18 (2): 125-8.

69. Fox VL, Nurko S, Teitelbaum J, Badizadegan K, Furuta GT. Highresolution EUS in children with eosinophilic "allergic" esophagitis. Gastrointest Endosc 2003; 57 (1): 30-6.

70. Fox VL, Nurko S, Teitelbaum J, Furuta GT. Abnormalities of the esophageal wall detectec by high-resolution probe endosonography in patinets with allergic esphagitis (abstract). J Pediatr Gastroenterol Nutr 2000; 31: S282. 
71. Mishra A, Schlotman J, Wang M, Rothenberg ME. Critical role for adaptative $\mathrm{T}$ cell immunity in experimental eosinophilic esophagitis in mice. J Leukoc Biol 2007; 81 (4): 916-24.

72. Landres RT, Kuster GGR, Strum WB. Eosinophilic esophagitis in a patient with vigorous achalasia. Gastroenterology 1978; 74 (6): 1298-301

73. Vitellas KM, Bennet WF, Bova JG, Johnston JC, Caldwell JH, Mayle JE. Idiopathic eosinophilic esophagitis. Radiology 1993; 186 (3): 789-93

74. Hempel SL, Elliott DE. Eosinophilic esophagitis causing esophageal dysmotility. Chest 1996; 110 (4): 1117-20.

75. Arora AS, Perrault J, Smyrk TC. Topical corticosteroid treatment of dysphagia due to eosinophilic esophagitis. Mayo Clin Proc 2003; 78 (7): 830-5.

76. Prieto G, Sánchez-Miranda P, Sarria JM, Larrauri J, Molina M. Esofagitis eosinofílica: una entidad clínica emergente (abstract). An Pediatr (Barc) 2003; 59 (3): 307-8.

77. Lucendo AJ, Castillo P, Martín-Chávarri S, Carrión G, Pajares R, Pascual JM, et al. Manometric findings in adult eosinophilic oesophagitis: a study of 12 cases. Eur J Gastroenterol Hepatol 2007; 19 (5): 417-24.

78. Borda F, Jiménez FJ, Martínez Peñuela JM, Echarri A, Martín Granizo I, Aznarez R. Esofagitis eosinofílica: ¿una entidad infradiagnosticada? Rev Esp Enferm Dig 1996; 88 (10): 701-4.

79. De Agustín JC, Sanz N, Canals MJ, Álvarez E, Morales JL, Soler J, et al. Successful medical treatment of two patients with eosinophilic oesophagitis. J Pediatr Surg 2002; 37(2): 207-13.

80. Gómez Chiari M, Martín de Carpi J, Castejón Ponce E, Villegas Villegas P, Masiques Mas ML, Varea Calderón V. Esofagitis eosinofílica: una entidad en aumento. A propósito de 8 casos. An Pediatr (Barc) 2003; 59(3): 128.

81. Orenstein SR, Shalaby TM, Di Lorenzo C, Putman PE, Sigurdsson L, Kocoshis SA. The spectrum of pediatric eosinophilic esophagitis beyong infancy: a clinical series of 30 children. Am J Gastroenterol 2000; 95 (6): 1422-30.

82. Flavahan NA, Slifman NR, Gleich GJ, Vanhoutte PM. Human eosinophil major protein causates hyperactivity of respiratory smooth muscle. Am Rev Resp Dis 1988; 138 (3): 685-8.

83. White SR, Ohno S, Muñoz NM, Gleich GJ, Abrahams C, Solway J, et al. Epithelium-dependent contraction of airway smooth muscle caused by eosinophil MBP. Am J Physiol Lung Cell Mol Physiol 1990; 259 (4 pt 1): L294-L303.

84. Lucendo AJ, Bellón T, Lucendo B. The role of mast cell in eosinophilic esophagitis. Pediatr Allergy Immunol 2008. DOI:10.1111/j.1399-3038.2008.00978.x.

85. Vanderhoff JA, Young RJ. Allergic disorders of the gastrointestinal tract. Curr Opin Clin Nutr Metab Care 2001; 4 (6): 553-6.

86. Lucendo AJ, Castillo P, Letrán A, Pascual-Turrión JM, Comas C, Caballero MT. Manometric findings in Eosinophilic esophagitis: Dynamic patterns and response to topical steroids (abstract). Gut 55 2006; (Supl. 5): A279.

87. Gonsalves N. Eosinophilic esophagitis: history, nomenclature, and diagnostic guidelines. Gastrointestinal Endosc Clin North Am 2008; 18 (1): 1-9.

88. Rosen R, Furuta G, Fritz J, Donovan K, Nurko S. Role of acid and nonacid reflux in children with eosinophilic esophagitis compared with patients with gastroesophageal reflux and control patients. J Pediatr Gastroenterol Nutr 2008; 46 (5): 520-3.

89. Mukkada V, Atkins D, Furuta GT. Uncertain Association of Barrett's Esophagus With Eosinophilic Esophagitis. Clin Gastroenterol Hepatol 2008; 6 (7): 832.

90. Aceves SS, Furuta GT, Spechler SJ. Integrated approach to treatment of children and adults with eosinophilic esophagitis. Gastrointestinal Endosc Clin North Am 2008; 18 (1): 195-217.

91. Molina-Infante J, Ferrando-Lamana L, Mateos-Rodríguez JM, PérezGallardo B, Prieto-Bermejo AB. Overlap of reflux and eosinophilic esophagitis in two patients requiring different therapies: a review of the literature. Wordl J Gastroenterol 2008; 14 (9): 1463-6.

92. Lucendo Villarín AJ. Immunopathological mechanisms of eosinophilic esophagitis. Allergol Inmunopathol (Madr) 2008; 36(4): 215-27.

93. Kagalwalla AF, Sentongo TA, Ritz S, Hess T, Nelson SP, Emerick $\mathrm{KM}$, et al. Effect of six-food elimination diet on clinical and histo- logic outcomes in eosinophilic esophagitis. Ciln Gastroenterol Hepatol 2006;4 (9): 1097-102.

94. Gonsalves N, Ritz S, Yang G, Ditto A, Hirano I. A prospective clinical trial of allergy testing and food elimination diet in adults with eosinophilic esophagitis (EE). Gastroenterology 2007; 132 (4): (Supl. 1); A-6-A-7.

95. Liacouras CA, Wenner WJ, Brown K, Ruchelli E. Primary eosinophilic esophagitis in children:successful tratment with oral corticosteroids. J Pediatr Gastroenterol Nutr 1998; 26 (4): 380-5.

96. Bory F, Vázquez E, Forcada P, Viver JM, Andreu M. Esofagitis eosinofílica como causa de disfagia de 10 años de evolución. Gastroenterol Hepatol 1998; 21 (6): 287-8.

97. Faubion WA, Perrault J, Burgart LJ, Zein NN, Clawson M, Furuta GT. Treatment of eosinophilic esophagitis with inhaled corticosteroids. J Pediatr Gastroenterol Nutr 1998; 27 (1): 90-3.

98. Teitelbaum J, Fox V, Twarog F, Nurko S, Antonioli D, Badizadegan $\mathrm{K}$, et al. Eosinophilic Esophagitis in children: inmunopathological analysis and response to fluticasone propionate. Gastroenterology 2002; 122 (5): 1216-25.

99. Konikoff MR, Noel RJ, Blanchard C, Kirby C, Jameson SC, Buckmeier BK, et al. A randomized double-blind, placebo controlled trial of fluticasone propionate for pediatric eosinophilic esophagitis. Gastroenterology 2006; 131 (5): 1381-91.

100. Langdon DE. Fluticasone in eosinophilic corrugated ringed esophagus. Am J Gastroenterol 2001; 96 (3): 926-7.

101. Aceves SS, Dohil R, Newbury RO, Bastian JF. Topical viscous budesonide suspension for treatment of eosinophilic esophagitis. J Allergy Clin Immunol 2005; 116 (3): 705-6.

102. Remedios M, Campbell C, Jones DM, Kerlin P. Eosinophilic esophagitis in adults: clinical, endoscopic, histologic findings, and response to treatment with fluticasone propionate. Gastrointest Endosc 2006; 63 (1): 3-12.

103. Perrault J, Arora AS, Clawson ML, Smyrk TC. Treatment of eosinophilic esophagitis with steoid lavage in adult patients (abstract). Am J Gastroenterol 2001; 96 (9): S31.

104. Schaefer ET, Fitzgerald JF, Molleston JP, Croffie JM, Pfefferkorn MD, Corkins MR, et al. Comparison of oral prednisone and topical fluticasone in the treatment of eosinophilic esophagitis: a randomized trial in children. Ciln Gastroenterol Hepatol 2008; 6 (2): 16573.

105. Moots RJ, Prouse P, Gumpel JM. Near fatal eosinophilic gastroenteritis responded to oral sodium cromoglycate. Gut 1988; 29 (9): 1282-5.

106. Attwood SE, Lewis CJ, Bronder CS, Morris CD, Armstrong GR, Whittam J. Eosinophilic esophagitis: a novel treatment using Montelukast. Gut 2003; 52 (2): 181-5.

107. Gupta SK, Peters-Golden M, Fitzgerald JF, Croffie JM, Pfefferkorn MD, Molleston JP, et al. Cysteinil leukotriene levels in esophageal mucosal biopsies of children with eosinophilic inflamation: are they all the same? Am J Gastroenterol 2006; 101 (5): 1125-8.

108. Netzer P, Gschossmann JM, Straumann A, Sendensky A, Weimann $R$, Schoepfer AM. Corticosteroid-dependent eosinophilic oesophagitis: azathioprine and 6-mercaptopurine can induce and maintain long-term remission. Eur J Gastroenterol Hepatol 2007; 19 (10): 865-9.

109. Cieslewicz G, Tomkinson A, Adler A, Duez C, Schwarze J, Takeda $\mathrm{K}$, et al. The late, but not early, asthmatic response is dependent on IL-5 and correlates with eosinophil infiltration. J Clin Invest 1999; 104 (3): 301-8.

110. Yamazaki K, Murray JA, Arora AS, Alexander JA, Smyrk TC, Butterfield $\mathrm{JH}$, et al. Allergen-specific in vitro cytokine production in adult patients with eosinophilic esophagitis. Dig Dis Sci 2006; 51 (11): 1934-41

111. Straumann A, Bauer M, Fischer B, Blaser K, Simon HU. Idiopathic eosinophilic esophagitis is associated with a $\mathrm{T}(\mathrm{H}) 2$-type allergic inflammatory response. J Allergy Clin Immunol 2001; 108 (6): 954-61.

112. Lucendo AJ, De Rezende L, Comas C, Caballero MT, Bellón T. Treatment with topic steroids downregulates IL-5, eotaxin-1/CCL11 and eotaxin-3/CCL26 gene expression in eosinophilic esophagitis. Am J Gastroenterol 2008; 103(9): 2184-93.

113. Mishra A, Hogan SP, Brandt EB, Rothenberg ME. IL-5 promotes eosinophil trafficking to the esophagus. J Inmunol 2002; 168 (5): 2464-9. 
114. Kim YJ, Prussin C, Martin B, Law MA, Haverty TP, Nutman TB, et al. Rebound eosinophilia after treatment of hypereosinophilic syndrome and eosinophilic gastroenteritis with monoclonal anti-IL-5 antibody SCH55700. J Allergy Clin Inmunol 2004; 114 (6): 1449-55.

115. Garrett JK, Jameson SC, Thomson B, Collins MH, Wagoner LE, Freese DK, et al. Anti-interluekin-5 (mepolizumab) therapy for hipereosinophilic syndromes. J Allergy Clin Inmunol 2003; 113 (1): 115-9.

116. Stein ML, Collins MH, Villanueva JM, Kushner JP, Putman PE, Buckmeier BK, et al. Anti-IL-5 (mepolizumab) therapy for eosinophilic esophagitis. J Allergy Clin Immunol 2006; 118 (6): 1312-9.

117. Straumann A, Conus S, Kita H, Kephart G, Bussmann C, Beglinger $\mathrm{C}$, et al. Mepolizumab, a humanized monoclonal antibody to IL-5, for severe eosinophilic esophagitis in adults: a randomized, placebocontrolled double-blind trial. J Allergy Clin Immunol 2008; 121 (1): (Supl. 1): S-44.

118. Echeverría Zudaire L, Fernández Fernández S, Rayo Fernández A, Bracamonte Bermejo T, Cilleruelo Pascual ML. No eficacia de omalizumab (Xolair) en el tratamiento de un paciente con esofagitis eosinofílica. Allergol Inmunopathol (Madr) 2008; 36 (Supl. 1): 689.

119. Sanjeevi A, Komorowski R, Shaker S, Massey BT, Shaker R, Saeian $\mathrm{K}$, et al. Eosinophilic esophagitis potencial sources for diagnostic error in histopathologic detection (abstract). Gastroenterology 2005; 128 (4): (Supl. 2): A-7.

120. Roberts-Thomson IC. Gastrointestinal: eosinophilic esophagitis. J Gastroenterol Hepatol 2005; 20 (8): 1299.

121. Zuber-Jerger I, Ratiu N, Kullman F. Long-lasting effect of endo- scopic dilation of an esophageal stenosis due to eosinophilic esophagitis. J Gastrointestin Liver Dis 2006; 15 (2): 167-70.

122. Kaplan M, Mutlu EA, Jakate S, Bruninga K, Losurdo J, Keshavarzian A. Endoscopy in eosinophilic esophagitis: "feline" esophagus and perforation risk. Ciln Gastroenterol Hepatol 2003; 1(6): 433-7.

123. Straumann A. The natural history and complications of eosinophilic esophagitis. Gastrointestinal Endosc Clin North Am 2008; 18 (1): 99-118.

124. Eisenbach C, Merle U, Schirmacher P, Hansmann J, Stiehl A, Stremmel W, et al. Perforation of the esophagus after dilation treatment for dysphagia in a patient with eosinophilic esophagitis. Endoscopy 2006; 38 (Supl. 2): E43-4.

125. De la Santa E, Lazo MD, Cordero C, Serrano M, López T, Bozada JM, et al. Esofagitis eosinofílica. Presentación de tres casos y reflexión sobre el papel de la endoscopia en una enfermedad probablemente infradiagnosticada. Libro de comunicaiones de la XXVI Jornada Nacional de la Sociedad Española de Endoscopia Digestiva. Madrid; 2004; 48.

126. Lucendo AJ, De Rezende L. Endoscopic dilation for treatment of eosinophilic esophagitis: a strategy with a high perforation risk. Endoscopy 2007; 39 (4): 376.

127. Schoepfer AM, Gschossmann J, Scheurer U, Seibold F, Straumann A. Esophageal strictures in adult eosinophilic esophagitis: dilation is an effective and safe alternative after failure of topical corticosteroids. Endoscopy 2008; 40 (2): 161-4.

128. Straumann A, Spichtin HP, Grize L, Bucher KA, Beglinger C, Simon HU. Natural history of primary eosinophilic esophagitis: a follow-up of 30 adults patients for up to 11.5 years. Gastroenterology 2003; 125 (6): 1660-9. 